\title{
Cytotoxic profiling of artesunic and betulinic acids and their synthetic hybrid compound on neurons and gliomas
}

\author{
Annemarie Ackermann ${ }^{1, *}$, Aysun Çapcı Karagözz, ${ }^{2}$, Ali Ghoochani ${ }^{1}$, Michael \\ Buchfelder $^{3}$, Ilker Eyüpoglu ${ }^{1,3}$, Svetlana B. Tsogoeva² and Nicolai Savaskan ${ }^{1,3,4}$ \\ ${ }^{1}$ Translational Cell Biology \& Neurooncology Laboratory, Universitätsklinikum Medical School Erlangen, Friedrich-Alexander \\ University of Erlangen - Nürnberg (FAU), Erlangen, Germany \\ ${ }^{2}$ Interdisciplinary Center for Molecular Materials (ICMM), Friedrich-Alexander University of Erlangen - Nürnberg (FAU), \\ Erlangen, Germany \\ ${ }^{3}$ Department of Neurosurgery, Universitätsklinikum Medical School Erlangen, Friedrich-Alexander University of Erlangen - \\ Nürnberg (FAU), Erlangen, Germany \\ ${ }^{4}$ BiMECON Ent., Berlin, Germany \\ *These authors have contributed equally to this work \\ Correspondence to: Nicolai Savaskan, email: savaskan@gmx.net or nic.savaskan@gmail.com \\ Svetlana B. Tsogoeva, email: svetlana.tsogoeva@fau.de \\ Keywords: cell death, cancer cytotoxicity, artesunic acid, betulinic acid, hybrid synthesis \\ Received: October 11, $2016 \quad$ Accepted: May 07, $2017 \quad$ Published: June 07, 2017 \\ Copyright: Ackermann et al. This is an open-access article distributed under the terms of the Creative Commons Attribution \\ License 3.0 (CC BY 3.0), which permits unrestricted use, distribution, and reproduction in any medium, provided the original author \\ and source are credited.
}

\section{ABSTRACT}

Gliomas are brain-born tumors with devastating impact on their brain microenvironment. Novel approaches employ multiple combinations of chemical compounds in synthetic hybrid molecules to target malignant tumors. Here, we report on the chemical hybridization approach exemplified by artesunic acid (ARTA) and naturally occurring triterpene betulinic acid (BETA). Artemisinin derived semisynthetic compound artesunic acid (ARTA) and naturally occurring triterpene BETA were used to synthetically couple to the hybrid compound termed 212A. We investigated the impact of $212 \mathrm{~A}$ and its parent compounds on glioma cells, astrocytes and neurons. ARTA and BETA showed cytotoxic effects on glioma cells at micromolar concentrations. ARTA was more effective on rodent glioma cells compared to BETA, whereas BETA exhibited higher toxic effects on human glioma cells compared to ARTA. We investigated these compounds on non-transformed glial cells and neurons as well. Noteworthy, ARTA showed almost no toxic effects on astrocytes and neurons, whereas BETA as well as 212A displayed neurotoxicity at higher concentrations. Hence we compared the efficacy of the hybrid $212 \mathrm{~A}$ with the combinational treatment of its parent compounds ARTA and BETA. The hybrid 212A was efficient in killing glioma cells compared to single compound treatment strategies. Moreover, ARTA and the hybrid 212A displayed a significant cytotoxic impact on glioma cell migration. Taken together, these results demonstrate that both plant derived compounds ARTA and BETA operate gliomatoxic with minor neurotoxic side effects. Altogether, our proofof-principle study demonstrates that the chemical hybrid synthesis is a valid approach for generating efficacious anti-cancer drugs out of virtually any given structure. Thus, synthetic hybrid therapeutics emerge as an innovative field for new chemotherapeutic developments with low neurotoxic profile. 


\section{INTRODUCTION}

Primary brain tumors are one of the most threatening conditions in oncology since effective curative therapies still do not exist $[1,2]$. The current strike force in treating malignant gliomas (WHO grade III and IV) is it first line surgery aiming at supra-complete tumor removal [2]. A cornerstone in neuro-oncology subsequently to surgery represents chemotherapy with cytotoxic drugs such as temozolomide, vincristin and cisplatin $[3,4,5]$ However, cytotoxic strategies have seminal disadvantages such as serious side effects and development of chemo resistance $[6,7]$. In fact, current standard chemotherapeutic drugs are mainly cytotoxic and are not selective for targeting cancer cells. Thus, there is an urge for novel compounds with high efficacy, specificity and low unintended side effects. Therefore, developments in cancer therapeutics concentrate on discovering drugs that selectively and effectively operate on cancer cells. Rising attention on natural products and their structures inspires the scientists to use them in drug discovery. During the last 30 years approximately $50 \%$ of the confirmed anticancer drugs are formed from natural products or their structures, such as paclitaxel (Taxol) or campthothecin as important anticancer drugs [8]. Besides, many of the other natural products and their derivatives are under investigations; such as Bevirimat which is a derivative of natural triterpene betulinic acid. Bevirimat [3-O-(3',3'dimethylsuccinyl)betulinic acid] is an antiretroviral agent which inhibits viral maturation (Figure 1). Bevirimat shows high activity against viruses in vitro and in vivo. This promising antiviral compound is in phase IIb clinical trials [9].

Another promising and fundamentally novel approach in order to obtain new specific anticancer active compounds with improved pharmacological properties is the hybridization of bioactive natural products: Two or more natural product fragments are combined and linked with each other via covalent bonds forming new hybrid molecules (Figure 2) [10, 11, 12, 13].

These synthetic hybrids containing partial structures of natural compounds are in many cases more active than their parent compounds $[14,15]$. As an example, the betulinic acid-thymoquinone hybrid has been reported superior to thymoquinone itself [16]. In the search for new drug candidates that specifically target brain tumors, we focused on the concept of hybridization, encouraged also by our previous results and experiences with artemisinin based hybrids [18, 19, 20, 21]. In this study, we focused on artesunic acid, a water soluble derivative of the natural antimalarial compound artemisinin - an enantiomerically pure sesquiterpene containing a 1,2,4-trioxane ring, which was extracted from the Chinese medicinal plant Artemisia аппиа L. in 1972 by Nobel laureate Youyou Tu [22].

Artesunic acid can induce cell death and oncogenesis in various cancer cells such as in breast cancer cells, T leukemia cells, myeloid leukemia and pancreatic cancer cells $[23,24,25,26]$. Mechanistically, artesunic acid mediates cytotoxicity via increased reactive oxygen species (ROS) generation. Artesunic acid has been found to induce lysosomal directed cell death, apoptosis, necrosis and ferroptosis dependent of the cell type [23, 26, 27].

As mentioned earlier, another promising class of natural compounds represents betulinic acid (BETA), which is an oxidation product of betulin (with $\mathrm{CH}_{2} \mathrm{OH}$ group instead of $\mathrm{COOH}$ at C-28). Particularly BETA itself has been reported as an antitumor agent in many constitutive studies and patents. BETA is a representative molecule from the pentacyclic triterpenoids with proven cell death inducing activity in various cancer cells [28, 29, 30]. Independent lines of research have shown that BETA induces apoptosis in breast cancer cells and melanoma cells [30, 31]. In contrast to ARTA, BETA has been shown to induce cell death also in some glioma cells [32]. Thus, many lines of evidence recognized BETA as a promising

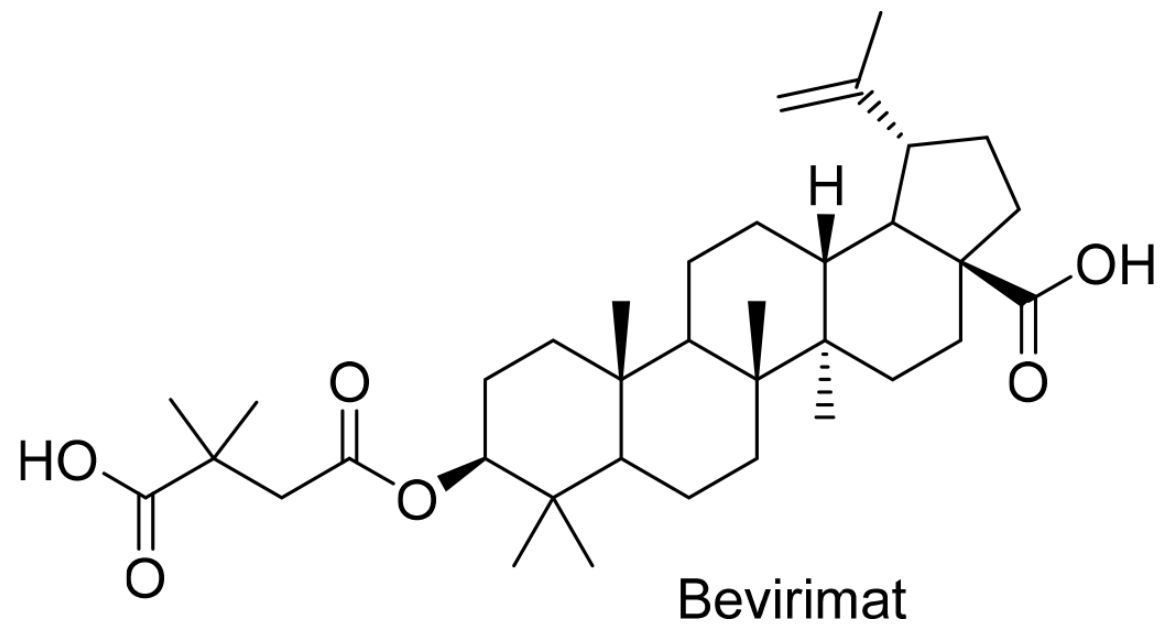

Figure 1: Structure of bevirimat. 
candidate as a chemotherapeutic. Strikingly, BETA's chemical properties such as poor solubility, lipophilicity, and cellular uptake efficacy were the main roadblocks for its routine medical practice [33]. Analogs of this natural product have been synthesized and analyzed to understand its chemistry and biology in order to enhance the properties like hydrosolubility together with higher cytotoxicity. A few of these analogs maintain the high cytotoxicity and selectivity against tumor cells. Attempts to achieve these analogs consist of modifications on the C-3, C-20 and C-28 carbon atoms of BETA structure which might increase the solubility according to previous studies [34].

We followed the strategy to first evaluate the impact of ARTA and BETA on various glioma cells as single compounds and then to perform the combination treatment with a 1:1 mixture of both single drugs. Second, we envisioned the idea of generating a synthetic hybrid of ARTA and BETA in order to combine each molecular properties, thereby boosting the cancer killing potential. Also, we considered the subtoxic and toxic doses on normal cellular constituents of the brain, namely neurons and astrocytes. Emerging evidence exists for enhanced efficacy when compounds are hybridized to increase potency or to generate novel biological functions $[18,19,20,21]$. Another advantage of hybrid molecules is the inexhaustible variety of potential new moieties with potential higher potency, different pharmacodynamics and specific pharmacokinetics.

Here, we present a comprehensive study on the biological effects of ARTA, BETA, their combinations and the hybrid molecule thereof on malignant brain tumor cells. We found that ARTA exhibits higher cytotoxic potential on rodent gliomas compared to BETA, whereas BETA was more effective on the human cell lines used in this study. Moreover, combined strategies either as

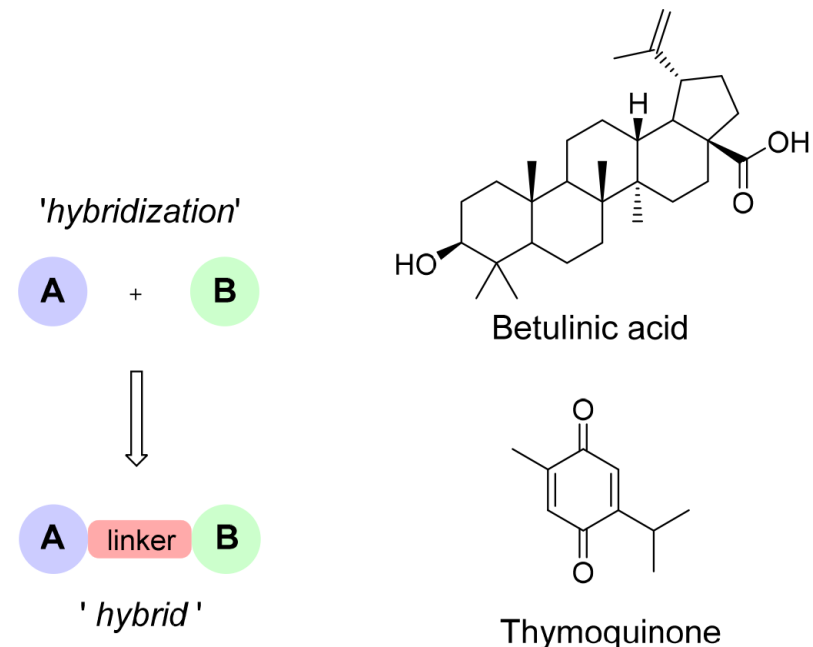

hybrid molecules or as combinations of ARTA and BETA even potentiated the biological activities in comparison to single molecule approaches.

\section{RESULTS}

\section{Generation of synthetic artesunic-betulinic acids hybrid compound}

When designing the hybrid molecule, we chose the position C-3 of BETA for coupling so at the position C-28 carboxylic acid group could be free which suggested the cause for higher activity of BETA compared to betulin. Previous studies showed that using various linkers is also affecting the activity, however, in this study the hybrid comprises directly of two compounds without additional linker. The coupling of parent compounds was expected to generate a synergistic effect between the components of the hybrids.

First, we synthesized artesunic acid pentafluorophenyl ester according to established procedures [17]. This active ester was reacted with betulinic acid in dry dimethylformamide (DMF) under $\mathrm{N}_{2}$ (Figure 3). The reaction mixture was stirred overnight and the crude product was purified via column chromatography resulting in hybrid $212 \mathrm{~A}$ with $75 \%$ yield (Figure 3 ). We further performed ${ }^{1} \mathrm{H}$ and ${ }^{13} \mathrm{C}$ NMR studies (Figure 4A, 4B) and mass spectra (ESIMS) analysis for the hybrid compound 212A (Figure 4C, see also Figure 5).

\section{Artesunic-betulinic acids hybrid induces cell shrinkage cell death in glioma cells}

First, we investigated the effects of artesunic acid, betulinic acid, the combination and the hybrid

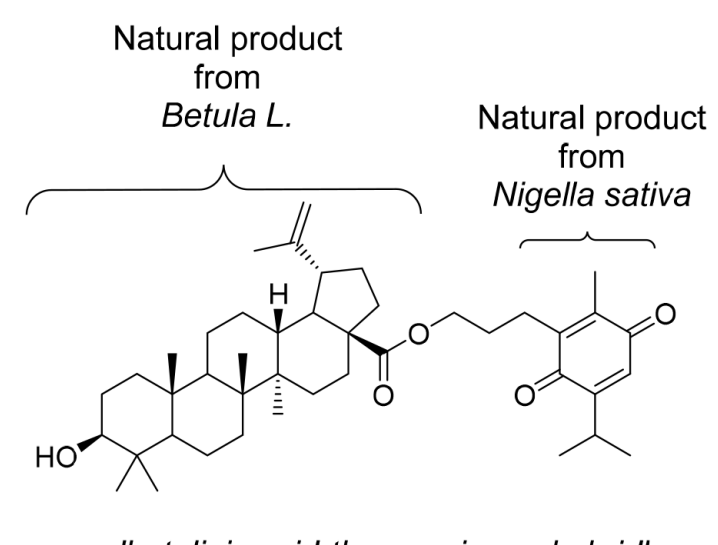

'betulinic acid-thymoquinone hybrid'

Highly active against melanoma, leukemia, cervix carcinoma and breast carcinoma cells

Figure 2: Natural products hybridization. Given is a scheme displaying the principle of the chemical hybrid synthesis concept. This chemical hybrid synthesis approach is a valid methodology for generating efficacious anti-cancer drugs out of virtually any given structure. Thus, synthetic hybrid therapeutics emerge as an innovative field for new chemotherapeutic developments. 
thereof on glioma cells. Therefore, we facilitated F98 glioma cells which were treated with a wide range of sole artesunic acid (ARTA, for NMR spectra see Figure 4D, 4E), betulinic acid (BETA, for NMR spectra see Figure 4F, 4G) concentrations, their hybrid (212A) and a combination of ARTA and BETA in order to investigate their morphological impact and glioma toxicity potential (Figure 6).

We found, that at the light microscopic level ARTA, 212A and the combination of ARTA and BETA challenged glioma cell morphology dramatically and glioma cells appeared fragmented and shriveled (Figure $6 \mathrm{~A})$. In contrast, the effects of BETA on cell morphology were less pronounced (Figure 6A). Our next task was to investigate whether morphological changes match to the effects on the cell viability. In glioma cells, both ARTA and BETA treatment significantly reduced glioma cell viability, although ARTA was more effective (Figure $6 \mathrm{~B})$. We found an effective concentration of ARTA at 5 $\mu \mathrm{M}$ to inhibit glioma cell proliferation (Figure $6 \mathrm{~A}, 6 \mathrm{~B}$ ). Furthermore we analyzed the cytotoxic potential of the synthetic hybrid molecule of ARTA and BETA termed 212A and compared the hybrid with the 1:1 combination of the single substances. Combined ARTA and BETA application was more efficient compared to single drug treatment (Figure 6B, 6C). Moreover, the hybrid 212A appeared also highly gliomatoxic although the impact of 212A compared to the combined applications of ARTA and BETA was almost the same (Figure 6C). These findings become even clearer in numbers. The $\mathrm{IC}_{50}$ for BETA of $5 \mu \mathrm{M}$ is the highest, followed by ARTA $\left(\mathrm{IC}_{50}: 3,8 \mu \mathrm{M}\right)$, their combination $\left(\mathrm{IC}_{50}: 2,3 \mu \mathrm{M}\right)$ and $212 \mathrm{~A}\left(\mathrm{IC}_{50}: 2 \mu \mathrm{M}\right)$ with the lowest concentration needed to achieve a $50 \%$ reduction of cell viability.

Next, we investigated the impact of the compounds on the glioma cytoskeleton. Glioma cells under control conditions showed a polygonal cell shape with many polymerized actin filaments (Figure 6F). Following ARTA application glioma cells presented almost no polymerized actin filaments and nuclei represented a condensed morphology (Figure 6F). In contrast, BETA treated glioma cells displayed only slight morphological changes with reduced cytoplasmatic sizes (Figure 6F). Noteworthy is the effect of 212A on glioma cells. 212A induced massive cell size reduction and increased cortical actin condensation compared to controls (Figure 6F). Also, nuclei showed fainted staining and fragmented morphology (Figure 6F). Combined ARTA and BETA treatment displayed similar morphological effects as 212A showed (Figure 6F).

Altogether, these results demonstrate that all used compounds are effective in reducing glioma proliferation.
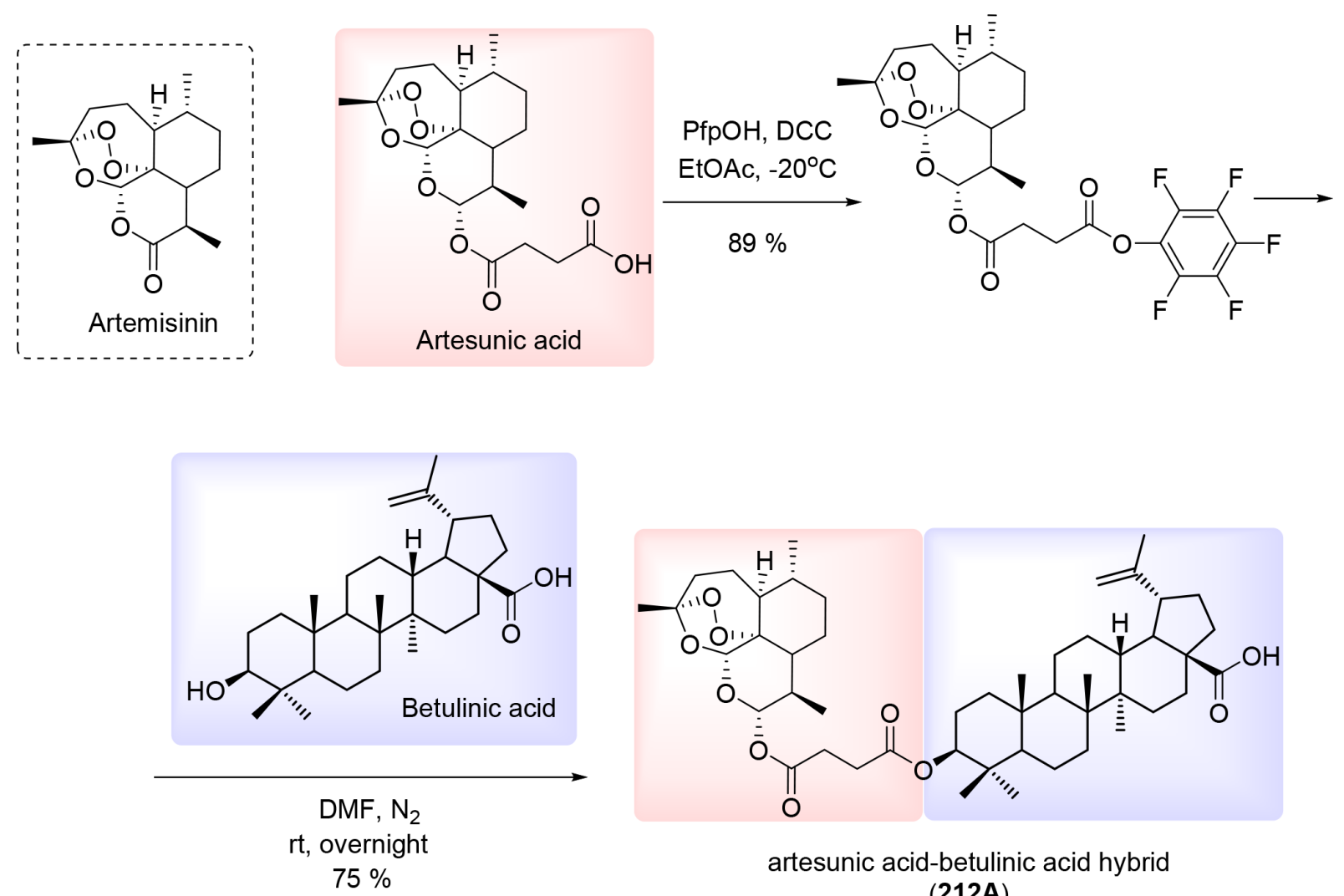

(212A)

Figure 3: Synthesis of artesunic and betulinic acids hybrid $212 \mathrm{~A}$. 
A

212A ${ }^{1} \mathrm{H} \mathrm{NMR}$ in $\mathrm{CDCl}_{3}$

喵

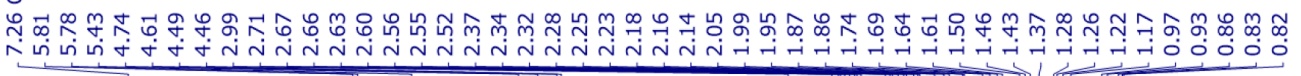
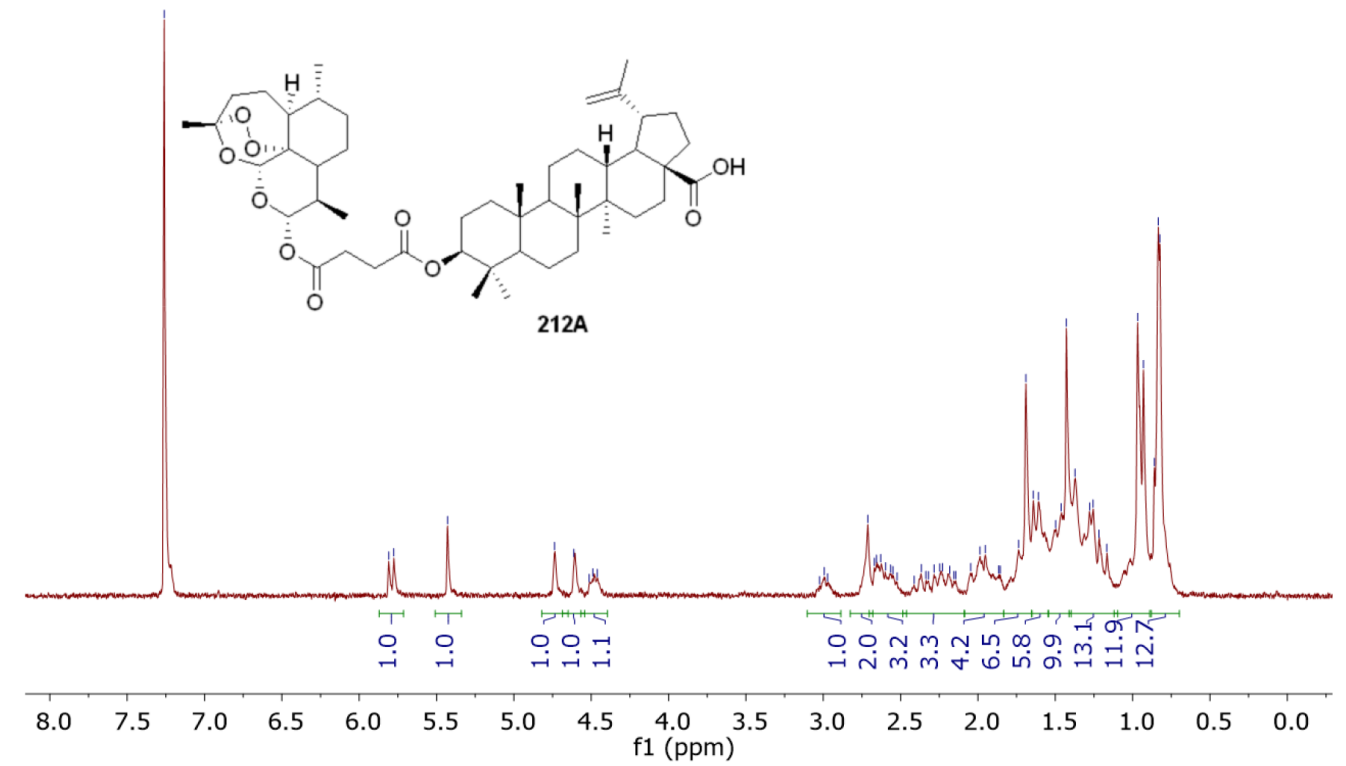

B

212A ${ }^{13} \mathrm{C} \mathrm{NMR} \mathrm{in} \mathrm{CDCl}_{3}$

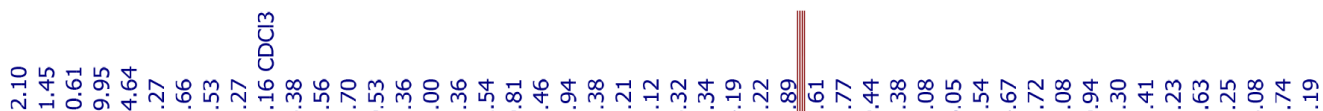

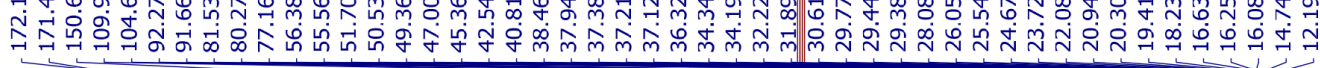

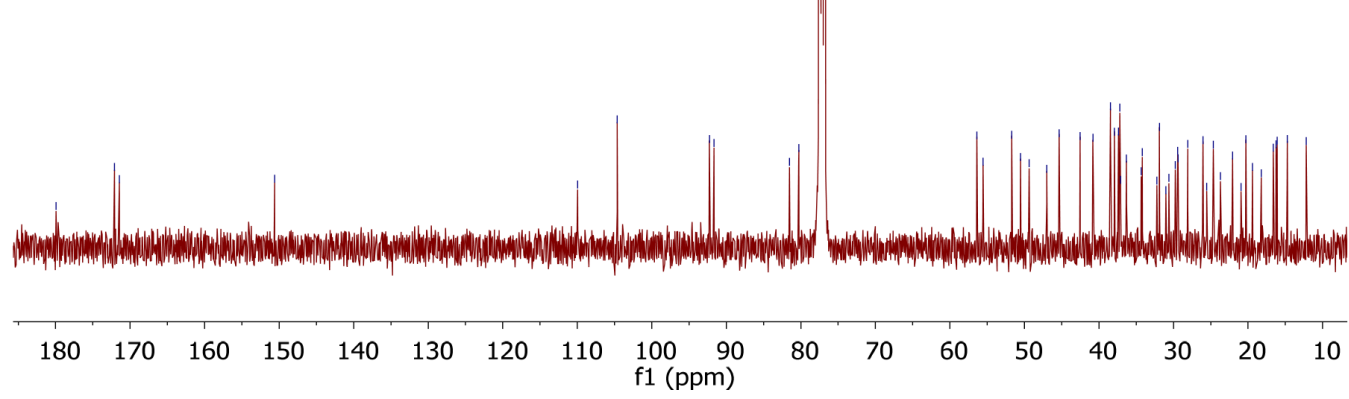

Figure 4: NMR and Mass spectra of hybrid compound 212A, BETA and ARTA. (A) ${ }^{1} \mathrm{H}-\mathrm{NMR}$ spectrum ( $300 \mathrm{MHz}, \mathrm{CDCl}_{3}$ ) of 212A. (B) ${ }^{13} \mathrm{C}-\mathrm{NMR}$ spectrum ( $75 \mathrm{MHz}, \mathrm{CDCl}_{3}$ ) of 212A. (Continued) 


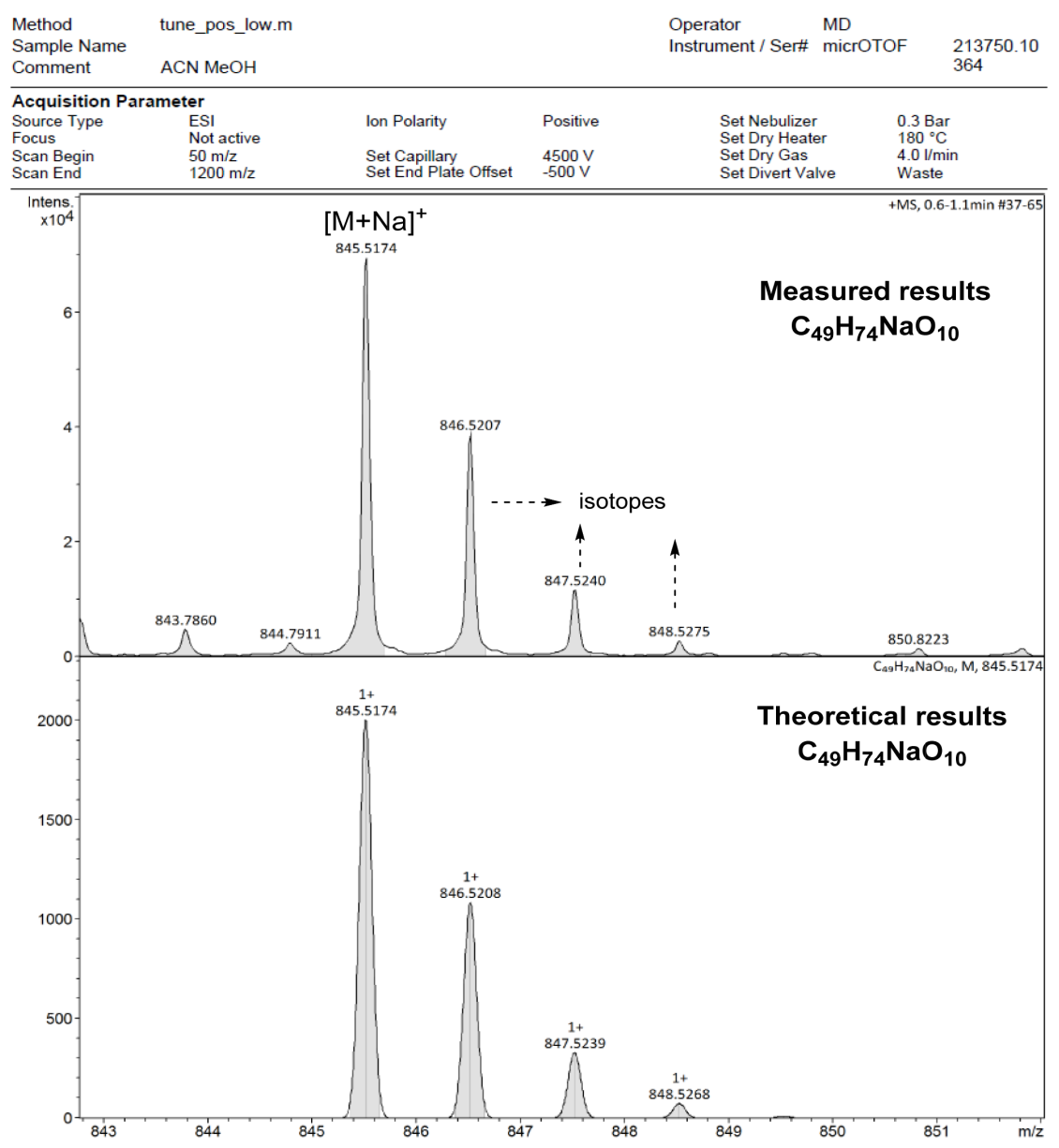

D

ARTA ${ }^{1} \mathrm{H}$ NMR in $\mathrm{CDCl}_{3}$

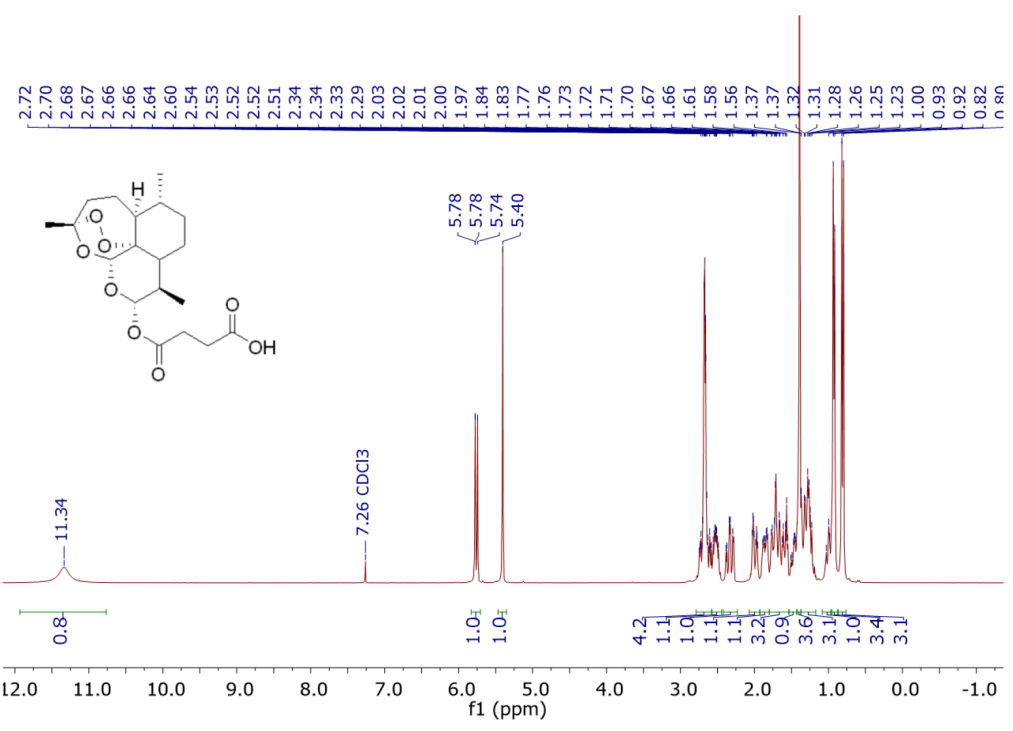

Figure 4: NMR and Mass spectra of hybrid compound 212A, BETA and ARTA. (C) ESI-MS spectrum of $212 \mathrm{~A}$. (D) ${ }^{1} \mathrm{H}-\mathrm{NMR}$ spectrum $\left(300 \mathrm{MHz}, \mathrm{CDCl}_{3}\right.$ ) of ARTA. (Continued) 
$\mathbf{E}$

ARTA ${ }^{13} \mathrm{C}$ NMR in $\mathrm{CDCl}_{3}$

$\begin{array}{cc}8 & 0 \\ 8 & 0 \\ 0 & -1 \\ 7 & 1 \\ 1 & 1\end{array}$
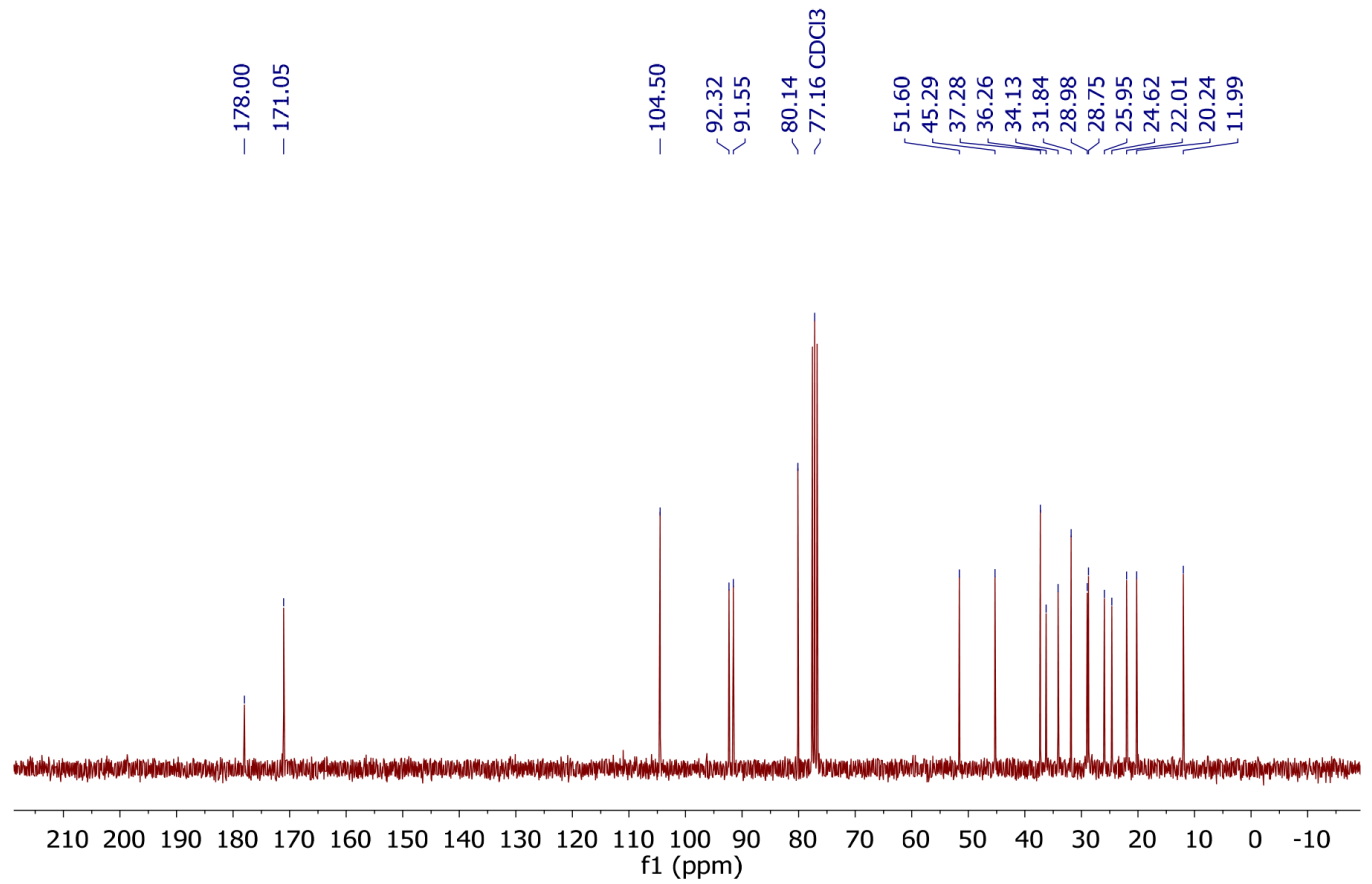

$\mathbf{F}$

BETA ${ }^{1} \mathrm{H}$ NMR in pyridine-d5
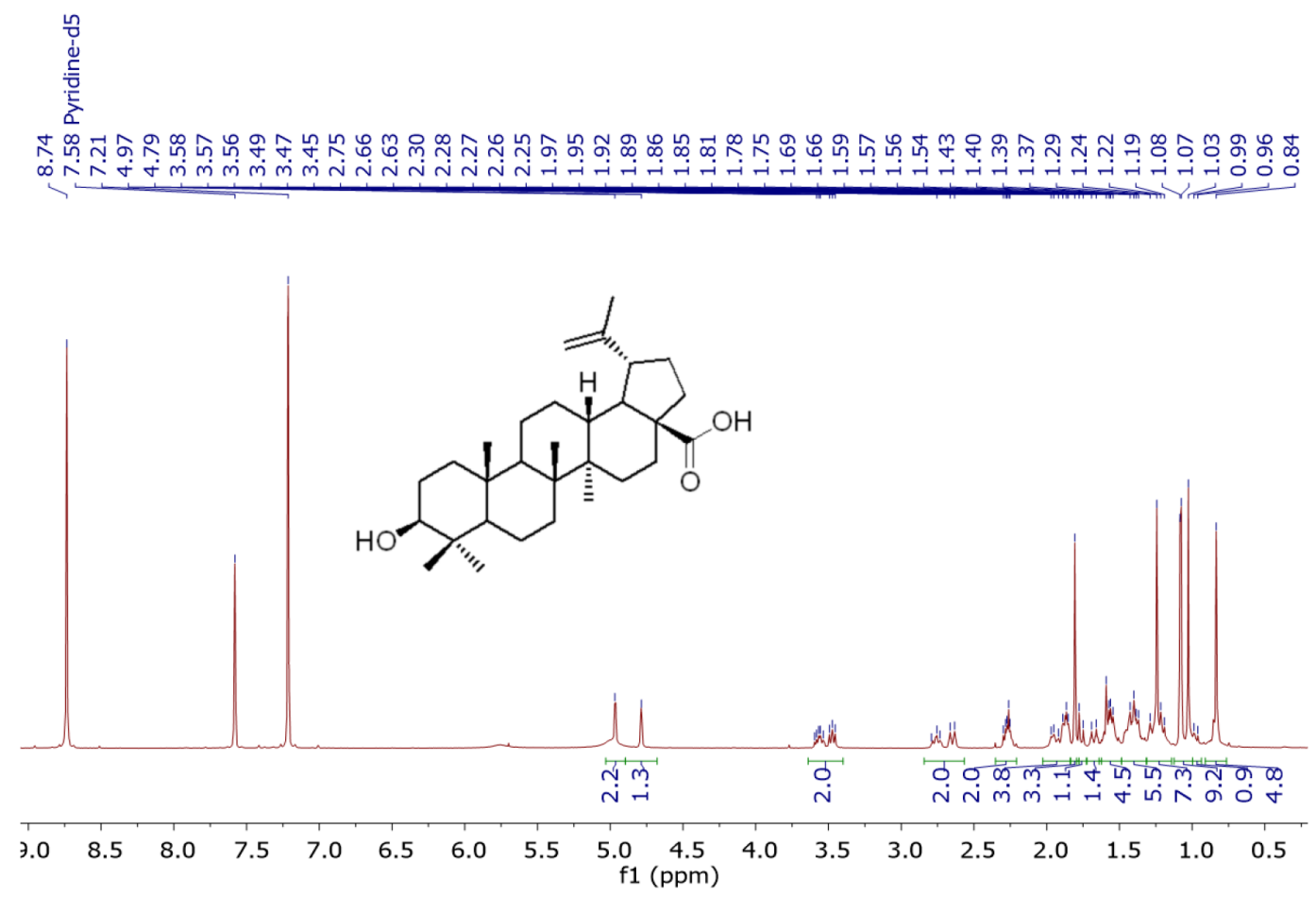

Figure 4: NMR and Mass spectra of hybrid compound 212A, BETA and ARTA. (E) ${ }^{13} \mathrm{C}-\mathrm{NMR}$ spectrum $\left(75 \mathrm{MHz}, \mathrm{CDCl}_{3}\right)$ of ARTA. (F) ${ }^{1} \mathrm{H}-\mathrm{NMR}$ spectrum ( $300 \mathrm{MHz}, \mathrm{CDCl}_{3}$ ) of BETA. (Continued) 


\section{G BETA ${ }^{13} \mathrm{C}$ NMR in pyridine-d5}

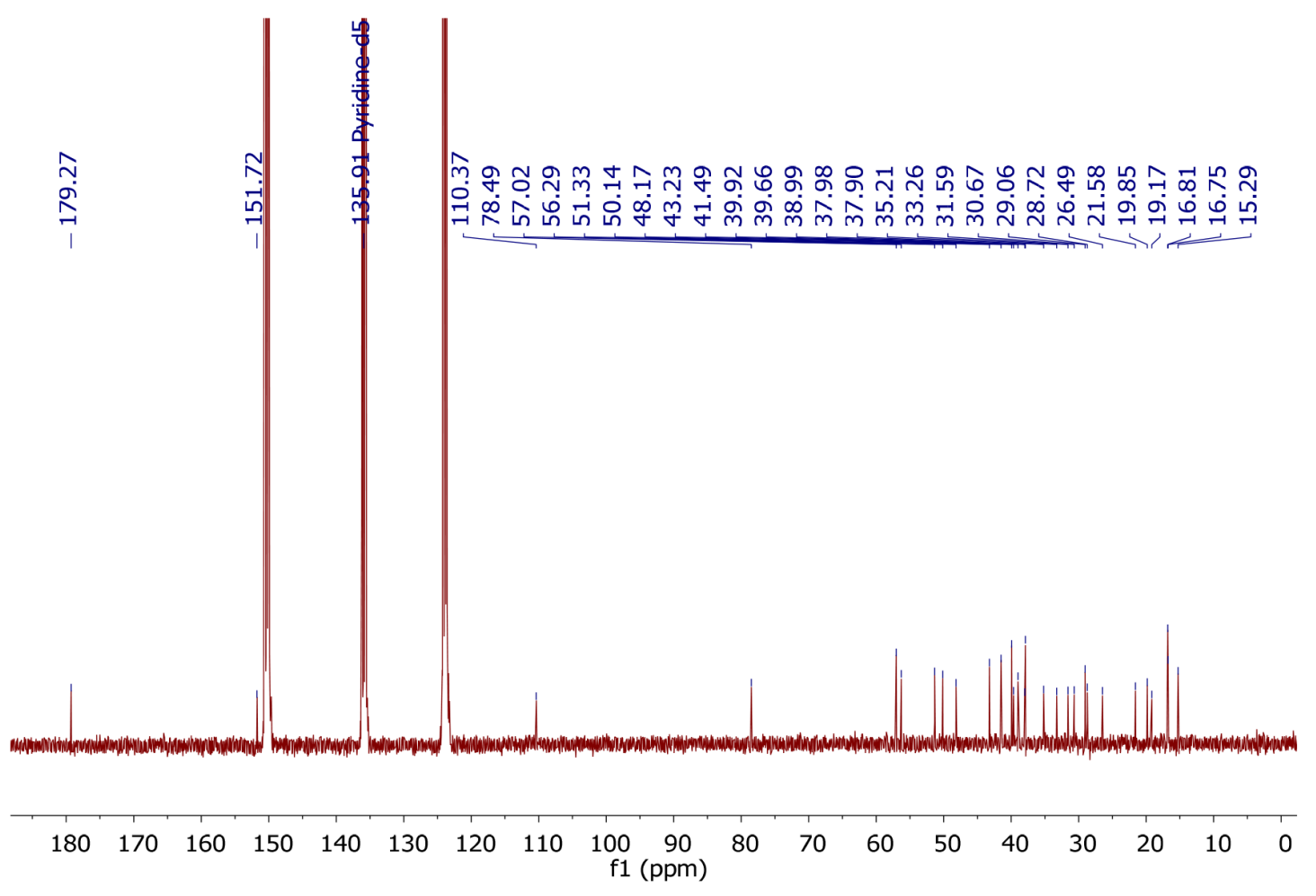

Figure 4: NMR and Mass spectra of hybrid compound 212A, BETA and ARTA. (G) ${ }^{13} \mathrm{C}-\mathrm{NMR}$ spectrum $(75 \mathrm{MHz}, \mathrm{CDCl}$ ) of BETA.

\section{ARTA and 212A are potent gliomatoxic compounds}

To analyze whether the reduction in cell viability correlates with gliomatoxicity or might have other reasons we performed a flow cytometry with the marker 7-Amino-actinomycin (7-AAD) and Annexin V. Therefore, cells were treated with $10 \mu \mathrm{M}$ of the compounds for 24h (Figure 6D, 6E). The results revealed a remarkable significant induction of 7-AAD positive cells which were treated with ARTA, 212A and the combination of ARTA and BETA (Figure 6D, 6E). This shows a major increase in cell death of any kinds of the cells treated with one of these substances. However, treatment of cells with BETA alone showed no considerable difference compared to the control group in terms of dead cells (Figure 6D, 6E). We next investigated Annexin V staining following treatment. Interestingly, all tested compounds revealed almost the same amount of Annexin $V$ positive cells (Figure 6D, 6E). These data indicate that $212 \mathrm{~A}$ and its parent compounds do not differ in inducing early apoptosis. A small part of the examined cells in each compounds group were both positive for Annexin $\mathrm{V}$ and 7-AAD (Figure 6D, $6 \mathrm{E})$. Controls and cells treated with BETA showed with around $1,5 \%$ the lowest amount of cells positive for both markers (Figure 6D, 6E). In contrast, ARTA, the hybrid and combination of ARTA and BETA displayed a higher number of stained cells for either dye on a comparable high level compared to controls (Figure 6D, 6E). This leads to the conclusion that only a small part of the cell death induced by the ARTA-related compound groups and ARTA itself is caused via apoptosis.

In summary, this experiment shows that the decrease in the metabolic activity and change of morphology of the cells treated with ARTA, 212A and the combinatorial treatment with ARTA and BETA can be attributed to a high induction of cell death. Whereas the results of the cells treated with BETA indicate that though we showed in our previous assays that the metabolic activity is decreased by this compounds, the cells might still be alive. Regarding the mechanism of cell death, the results suggest that the major part of the cells treated with ARTA or one of the ARTA related substances did not die via apoptosis because most of the cells were solely positive for Annexin V. 


\section{Artesunic acid, betulinic acid and their hybrid 212A show toxic effects on human glioma cells}

Next, we examined the impact of our substances on human glioma cells. Therefore, we treated U87 and TN22 with ARTA, BETA, 212A and the combination of the single compounds with different concentrations $(1 \mu \mathrm{M}$, $5 \mu \mathrm{M}, 10 \mu \mathrm{M}$ and $20 \mu \mathrm{M}$ ) for again $72 \mathrm{~h}$.

Interestingly, none of the compounds or combinations showed a significant effect on the morphology of the human glioma cells in light microscopy (Figure 7A). The next step was to examine the cell viability. All used treatments reduced the cell viability significantly. Noteworthy, ARTA had the least impact on the cells, already the treatment with $1 \mu \mathrm{M}$ with BETA showed a similar effect as $20 \mu \mathrm{M}$ of ARTA (Figure 7B). Whereas the effect of BETA and the combinatorial treatment with ARTA were most effective especially in lower concentrations (Figure 7B, 7C). Comparing the reduction in cell viability after the application of $212 \mathrm{~A}$ or ARTA in combination with BETA, our experiments disclosed that in higher concentration $(20 \mu \mathrm{M})$ both decreased the cell viability by about the same level, while the combination of the single compounds seemed more effective in lower concentrations significantly even if using only $1 \mu \mathrm{M}$ (Figure 7C). Further, we analyzed whether our findings of the cell viability assay can be also seen performing a propidium iodide staining. The propidium iodide staining indicated a higher rate of cell death in the groups treated with BETA, 212A and the combination of ARTA and BETA compared to control (Figure 7D, 7E). We found the highest amount of cell death at the combination treatment with ARTA and BETA and the single treatment of BETA (Figure 7D, 7E). ARTA did not show any effect compared to the cells without treatment regarding the propidium iodide staining (Figure 7D, 7E). Since these findings match to our previous experiments, it seems that the reduction of cell viability is caused mostly by cell death. To support the results so far made, we measured the cell viability of another human glioma cell line (TN22) for one concentration (10 $\mu \mathrm{M})$ as an example. Also when treating TN22 BETA, its combination with ARTA and 212A showed the greatest impact on the glioma cells (Figure 7F).

Comparing all these findings with the results of the rodent cell line it can be noticed that, whereas ARTA seemed more effective when treating F98 (Figure 6B), BETA showed a significant greater effect in reducing the cell viability compared to ARTA on the human cell line U87 and TN22 at lower concentrations $(1 \mu \mathrm{M}, 5 \mu \mathrm{M}$, $10 \mu \mathrm{M})($ Figure 7B). Furthermore in these experiments we showed that all substances decreased the cell viability of human glioma cells and that especially for BETA, 212A and the combination of ARTA and BETA this can be attributed to an increase of cell death (Figure 6B-6E). This indicates that though the cell death analysis we performed with the rodent cell line showed that the reduction of cell viability of the cells treated with BETA might not be caused by cell death, BETA can still be seen as a potential gliomatoxic drug for human cells.

\begin{tabular}{|c|c|c|c|c|c|c|c|c|}
\hline Compound & $\begin{array}{c}\text { Molecular } \\
\text { formula }\end{array}$ & $\begin{array}{c}\text { Molecular } \\
\text { weight }\end{array}$ & $\begin{array}{c}\text { Melting } \\
\text { point }\end{array}$ & $\mathbf{R}_{\mathbf{f}}{ }^{(\mathbf{a})}$ & EA $^{(\mathbf{b})}$ & $\begin{array}{c}{ }^{1} \mathrm{H}^{\text {and }}{ }^{13} \mathbf{C} \\
\text { NMR }^{(\mathbf{c})}\end{array}$ & ESI-MS & Color \\
\hline BETA & $\mathrm{C}_{30} \mathrm{H}_{48} \mathrm{O}_{3}$ & 456.71 & $316^{\circ} \mathrm{C}$ & 0.47 & + & Fig. $4 \mathrm{~F}, \mathrm{G}$ & $\begin{array}{c}{[\mathrm{M}-\mathrm{H}]^{-}} \\
456\end{array}$ & $\begin{array}{c}\text { White } \\
\text { powder }\end{array}$ \\
\hline ARTA & $\mathrm{C}_{19} \mathrm{H}_{28} \mathrm{O}_{8}$ & 384.42 & $132^{\circ} \mathrm{C}$ & 0.13 & + & Fig. 4D,E & $\begin{array}{c}{\left[\mathrm{M}+\mathrm{NH}_{4}\right]^{+}} \\
402 \text { (e) }\end{array}$ & $\begin{array}{c}\text { White } \\
\text { crystalline } \\
\text { powder }\end{array}$ \\
\hline $\mathbf{2 1 2 A}$ & $\mathrm{C}_{49} \mathrm{H}_{74} \mathrm{O}_{10}$ & 823.12 & $155^{\circ} \mathrm{C}$ & 0.30 & + & Fig. 4A,B & $\begin{array}{c}{[\mathrm{M}+\mathrm{Na}]^{+}} \\
845.5\end{array}$ & $\begin{array}{c}\text { White } \\
\text { powder }\end{array}$ \\
\hline
\end{tabular}

a) $\quad R_{f}$ values were determined in the solvent mixture of hexane : ethylacetate $(4: 1)$.

b) All compound purities were confirmed by EA (elemental analysis). .

c) The NMR spectra are provided in Figure 4.

d) Ref. [38]

e) Ref. [39]

Figure 5: Properties of investigated parent compounds and hybrid 212A. $\mathrm{R}_{\mathrm{f}}$ values were determined in the solvent mixture of hexane : ethylacetate (4:1). All compound purities were confirmed by EA (elemental analysis). The NMR spectra are provided in Figure 4. 


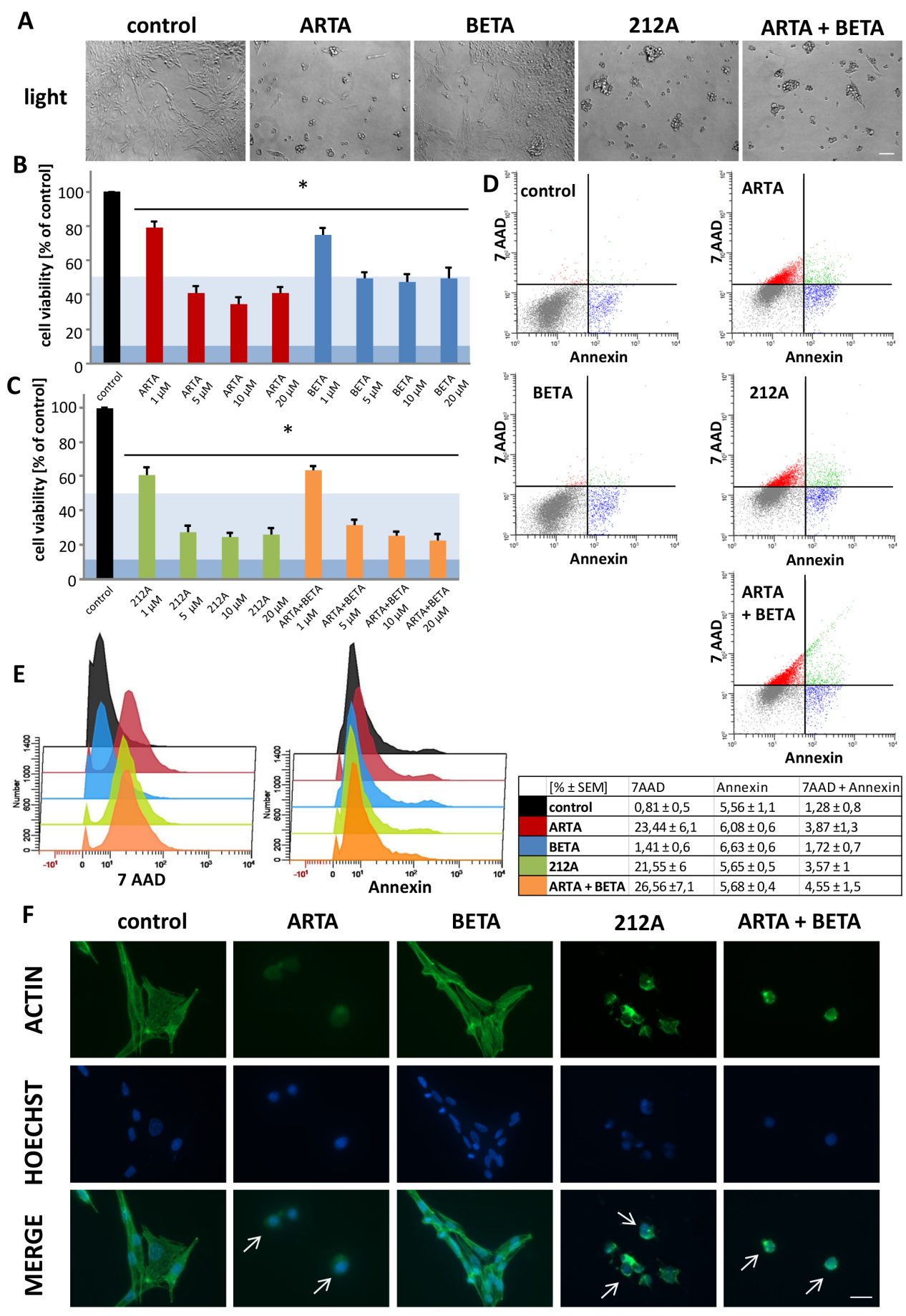

Figure 6: Cytotoxic profile of Artesunic acid, Betulinic acid and the hybrid 212A on rodent glioma cells. (A) Rat glioma cells (F98) were treated with $5 \mu \mathrm{M}$ of ARTA, BETA, 212A and ARTA combined with BETA. Cell morphology was examined after 72h with light microscopy. Scale bars, $200 \mu \mathrm{m}$. (B, C) F98 were treated with different concentrations of ARTA, BETA, 212A and ARTA combined with BETA. Cell viability was measured after $72 \mathrm{~h}$. Statistical significance was tested with unpaired two-sided t-test vs. control ( $\mathrm{n} \geq 4 ;{ }^{*}, \mathrm{p}$ $\leq 0.05$ ). The light blue marking indicates the value of $\mathrm{IC}_{50}$ and the dark blue one stands for $\mathrm{IC}_{90}$ value. This is passable for the following figures. (D, E) Rodent cells were treated with $10 \mu \mathrm{M}$ of the compounds. Cell death analysis was performed after 24h with 7 AAD and Annexin V. Statistical significance was tested with unpaired two-sided t-test vs. control ( $\mathrm{n} \geq 4 ; \mathrm{p} \leq 0.05)$. (F) F98 were treated with $10 \mu \mathrm{M}$ of ARTA, BETA, 212A and ARTA combined with BETA. Cells were fixated and stained with actin marker Phalloidin 488 and DNA marker Hoechst after 48h. Scale bars represent $20 \mu \mathrm{m}$. 


\section{Artesunic acid and betulinic acid show no} significant neurotoxic and gliotoxic impact at low concentrations

The next step was to investigate the ARTA compounds and BETA for their impact on healthy brain cells. Therefore, primary neurons and astrocytes were extracted from rodent brain and treated with $5 \mu \mathrm{M}$ and
$10 \mu \mathrm{M}$ of ARTA, BETA, their combination and the hybrid 212A (Figure 8). First, to examine the morphological effects we fixed the treated cells and analyzed the cytoskeleton. There were no changes visible in structure or density between the treated groups and controls. Neurons showed complex dendritic arborization which was not affected by ARTA, BETA or 212A (Figure 8A). To investigate the number of dead cells we stained neuronal

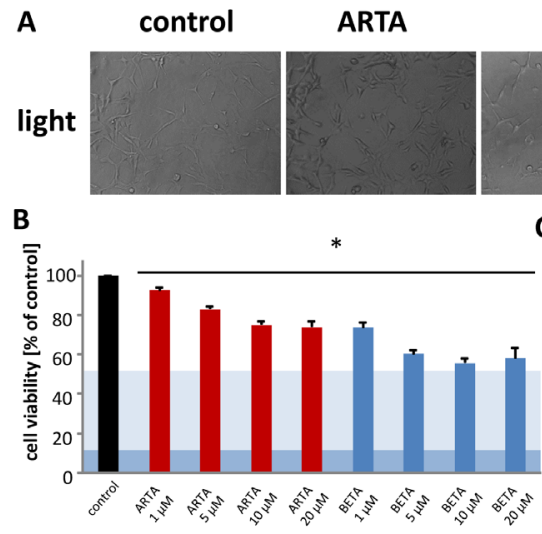

BETA

212A ARTA+ BETA

D

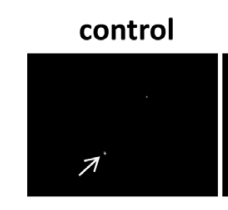

ARTA
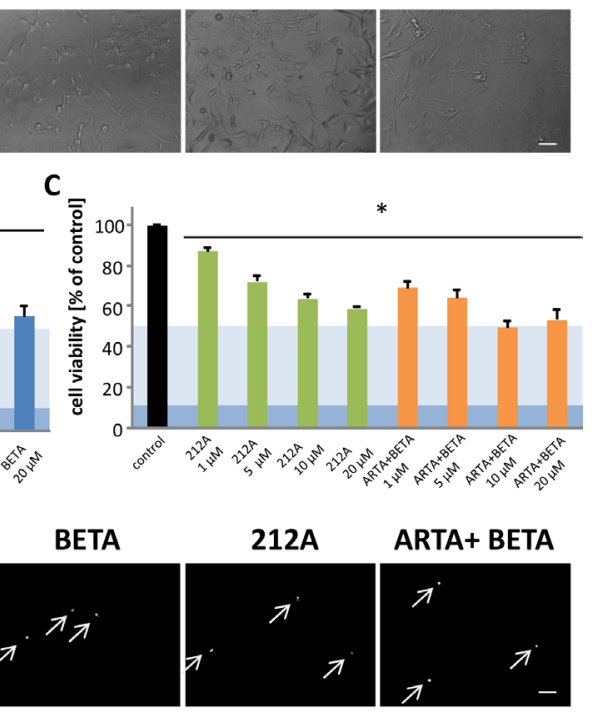
cells co-cultured with astrocytes with propidium iodide staining after treatment with a concentration of $10 \mu \mathrm{M}$ for each compound with duration of $72 \mathrm{~h}$. An increased number of cell death was displayed following treatment with BETA and the combination of ARTA with BETA (Figure 8B). These results correlate partially with our findings of the cell viability assays after treating cells with a concentration of $10 \mu \mathrm{M}$, whereas ARTA showed no significant difference compared to controls. In the other three treatment groups (containing BETA, 212A and the combination of ARTA and BETA) a decrease in cell viability was detected (Figure 8D).

Next step was to find out how primary neurons and astrocytes react, exposed to a lower concentration of these compounds. For this we applied a concentration of $5 \mu \mathrm{M}$ for each compound and their combinations. The cell viability assays indicated no significant neurotoxic and gliotoxic effect for ARTA, BETA and their combination, whereas 212A still had a significant impact (Figure 8C).

Overall these results combined with the toxic effect on the glioma cells already at the concentration of $5 \mu \mathrm{M}$ demonstrate the value of ARTA and BETA to combat gliomas, especially ARTA, with no change in cell viability at higher concentrations $(10 \mu \mathrm{M})$.

\section{Artesunic acid, the combination of artesunic and betulinic acids and their hybrid $212 \mathrm{~A}$ inhibit the migration of glioma cells}

Next, we investigated the impact of ARTA, BETA and 212A on glioma migration since this biological feature is clinically highly relevant and has not been solved up to now. Therefore, cells were plated into a 12-well-plate, after $36 \mathrm{~h}$ a scratch was made, afterwards cells were treated with $5 \mu \mathrm{M}$ (Figure 9A, 9B) and $10 \mu \mathrm{M}$ (Figure 9C, 9D) of the compounds and monitored at various times. $12 \mathrm{~h}$ after the treatment there is no difference in migration visible between the treated cells and the control in both concentrations (Figure 9). Whereas after 24h, we observed a significant difference of the migration distance between the control and artesunic acid in both the lower and the higher concentration, though betulinic acid showed no or only a slight difference in migration compared to the control after 24h (Figure 9B, 9D). Also cells treated with $212 \mathrm{~A}$ with the higher concentration showed significantly less migration, whereas the decrease in migration in cells treated with the combination of single ARTA and BETA was less pronounced (Figure 9D). After 36h, besides the ARTA and 212A treatment, the experiment also showed a significant decrease in migration for the combined ARTA and BETA treatment (Figure 9A, 9B). After 2 days all treatment groups including ARTA (ARTA, 212A, ARTA + BETA) showed significant less glioma cell migration (Figure 9). The cells treated with $10 \mu \mathrm{M}$ of ARTA combined with BETA were less attached to the plate and settled in groups so that these results could not be quantified (Figure 9C). In contrast, BETA did not show any effects on glioma cell migration (Figure 9). Interestingly comparing the migration distance between the concentrations there is a significant difference between cells treated with $5 \mu \mathrm{M}$ and $10 \mu \mathrm{M}$ of $212 \mathrm{~A}$ at $24 \mathrm{~h}$ and $48 \mathrm{~h}$ though this phenomenon cannot be identified for sole ARTA, BETA and their combination treatment (Figure 9B, 9C).

In summary, these results show that ARTA, 212A and the combination of ARTA and BETA inhibit glioma cell migration on more or less the same level, whereas no such effect was found for BETA.

\section{DISCUSSION}

Still, malignant gliomas are primary brain tumors with fatal outcome. The frontline therapy in most glioblastoma patients with or without neurosurgery represents chemotherapy [4]. Chemotherapy aims at killing glioma cells at concentrations where normal brain cells have chances to survive. This cytotoxic strategy therefore depends on compounds which fulfill the requirements to be specifically toxic to cancer cells. Thus, major focus is on discovering agents or small molecules with high ability to passively diffuse across the blood-brain barrier and impact specifically on glioma cells [2]. We describe here a new therapeutic technology to combat gliomas by combining small molecules through the chemical hybridization approach [10]. This concept itself is not novel; however, the application of such hybrid molecules in neuro-oncological settings and in particular in glioma research has to our knowledge not been described before.

We found a cytotoxic effect of BETA, already using concentrations of $5 \mu \mathrm{M}$ which correlates with previous studies on malignant brain-tumor cells [29]. In fact, betulinic acid (BETA) is a promising anti-cancer natural compound and a representative molecule from the pentacyclic triterpenoids. BETA has been shown to be toxic in various cancer cells such as in breast cancer cells and melanoma cells [28, 30, 31]. Thus, many lines of evidence recognized BETA as a promising chemotherapeutic candidate. Strikingly, BETA's chemical properties such as poor solubility, lipophilicity, and cellular uptake efficacy were the main roadblocks for its routine medical practice [33] which may explain why BETA has only some pre-clinical studies [35].

In contrast, artesunic acid entered clinical medicine with the application in malaria infection [22]. ARTA is a water-soluble derivative of artemisinin which was extracted from the Chinese medicinal plant Artemisia annua L. ARTA can induce cell death and oncogenesis in various cancer cells such as in breast cancer cells, T leukemia cells, myeloid leukemia and pancreatic cancer cells [23, 24, 25, 26]. Mechanistically, ARTA mediates cytotoxicity via increased reactive oxygen species (ROS) 
generation lysosomal directed cell death, apoptosis, necrosis and ferroptosis dependent of the cell type [23, $26,27]$. However, somehow unexpected was the efficacy of ARTA on gliomas. ARTA appears gliomatoxic at low concentrations and at the same time exhibits only minor toxic effects on primary neurons and astrocytes. This motivated us to test ARTA and ARTA derived hybrid combined with the known compound BETA. In fact, previous work of our laboratory and others revealed promising effects of ARTA derived hybrids against
Plasmodium falciparum, multidrug-resistant leukemia cells and viruses $[18,19,20,21]$.

We set out the strategy to investigate the impact of ARTA and BETA on various glioma cells as single compounds, in combination with a ratio of $1: 1$ mixture of both single drugs and as a hybrid of ARTA and BETA. The hybrid approach was aimed to combine the advantage of both compounds to boost the cancer killing potential. In fact, $212 \mathrm{~A}$ revealed the lowest $\mathrm{IC}_{50}$ value in rodent gliomas. Another feature of $212 \mathrm{~A}$ is that glioma cell
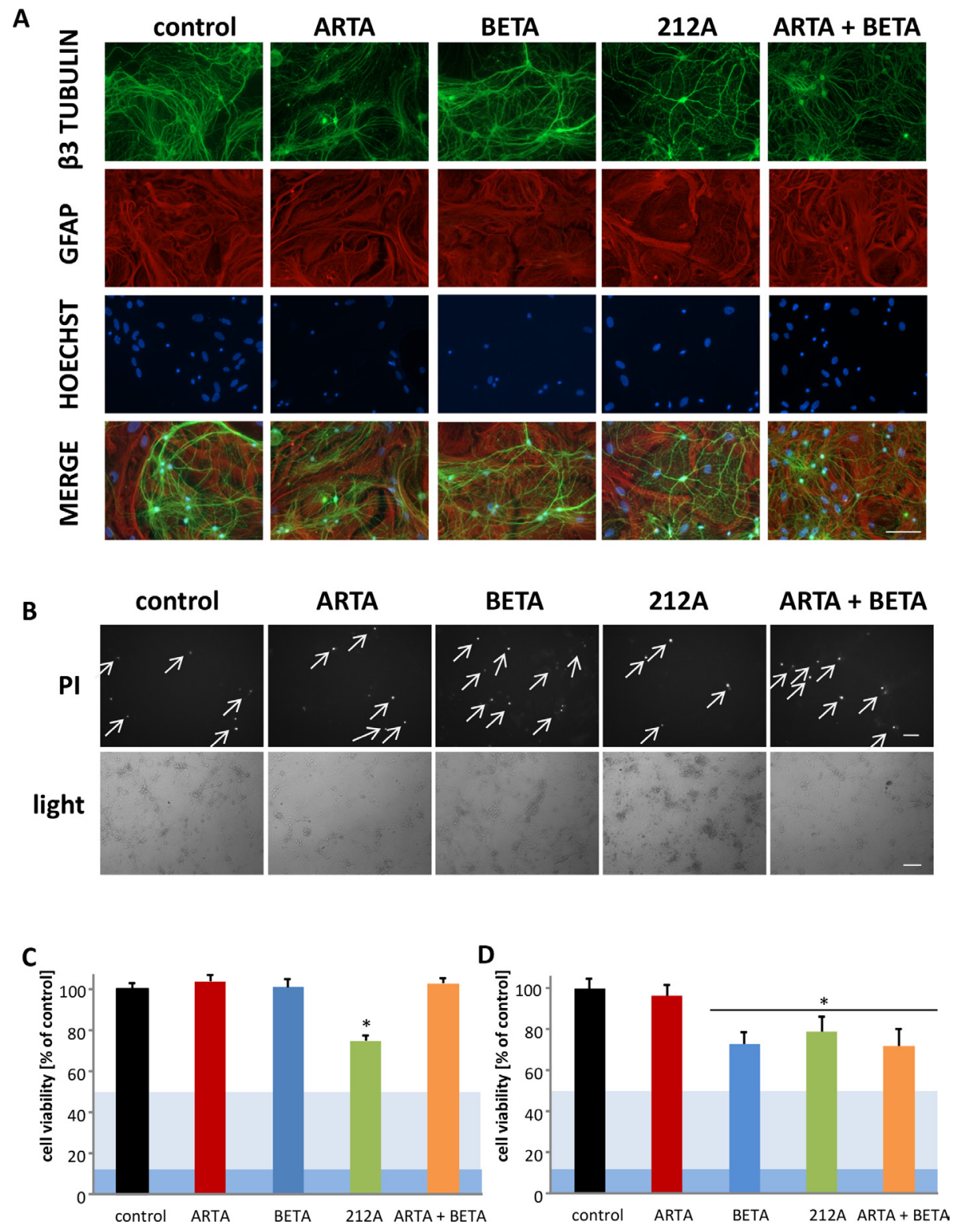

Figure 8: Neurotoxicity and gliomatoxicity profiling of Artesunic acid, Betulinic acid and the hybrid 212A. (A) Primary neurons and astrocytes were treated with $10 \mu \mathrm{M}$ ARTA, BETA, 212A and ARTA in combination with BETA. After 72h cells were fixed and immunostained for the neuronal marker beta-III- tubulin, the glial marker GFAP and the DNA marker Hoechst. Scale bars, $100 \mu \mathrm{m}$. (B) Primary neurons and astrocytes were treated with $10 \mu \mathrm{M}$ of ARTA, BETA, 212A and ARTA combined with BETA. Cell death was examined after $72 \mathrm{~h}$ with propidium iodide (PI) and light microscopy. Scale bars, $200 \mu \mathrm{m}$. (C, D) Primary neurons and astrocytes were treated with $5 \mu \mathrm{M}(\mathbf{C})$ and $10 \mu \mathrm{M}$ (D) of ARTA, BETA, 212A and ARTA combined with BETA. Cell viability was measured after 72h. Statistical significance was tested with unpaired two-sided t-test vs. control $(\mathrm{n} \geq 5 ; *, \mathrm{p} \leq 0.05)$. 
migration can be mitigated by the hybrid $212 \mathrm{~A}$. This is an interesting finding, since BETA has almost no effects on glioma migration. However, the differences in glioma toxicity between ARTA and 212A are low. In addition, 212A has a certain neurotoxic potential at least at high levels. Since ARTA shows almost no unintended side effects it is unlikely that $212 \mathrm{~A}$ will be a realistic candidate for clinical applications in neuro-oncology. Although there is a quest for new small molecule compounds which should turn into novel therapies, our study also shows that at least in the case of ARTA and BETA, combined treatments are equally efficient as hybrids. In this work, artesunic acid and betulinic acid were investigated for the first time against glioblastoma. This is the main focus of

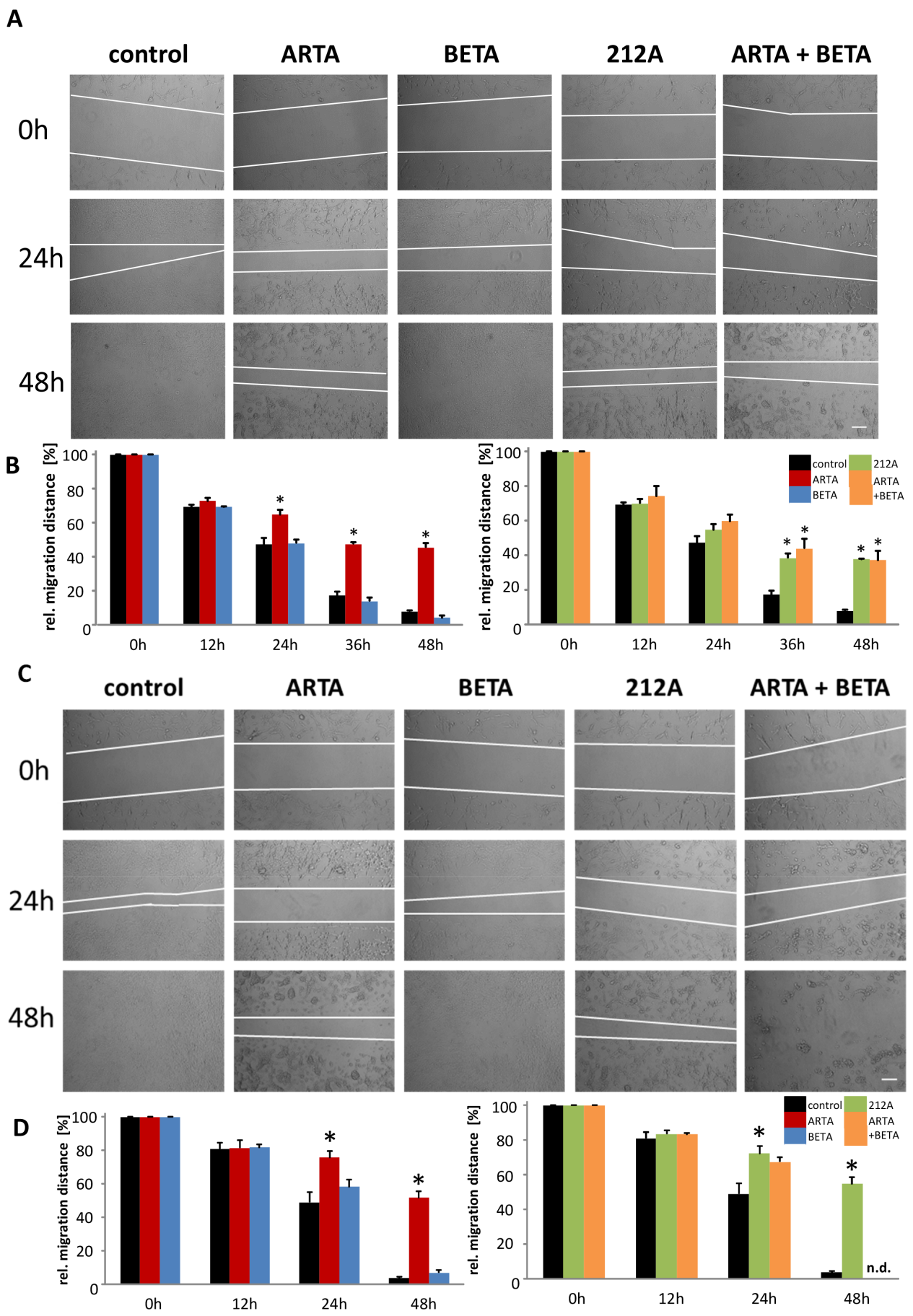

Figure 9: Extent of inhibition of cell migration by Artesunic acid, Betulinic acid and the hybrid on rodent glioma cells. (A, C) A scratch was made into plated cells which were then treated with $5 \mu \mathrm{M}(\mathbf{A})$ and $10 \mu \mathrm{M}(\mathbf{C})$. Results were observed at different times. (B, D) Migration distance of the treatment with $5 \mu \mathrm{M}$ (B) and $10 \mu \mathrm{M}$ (D) were quantified and compared to the data from $0 \mathrm{~h}$. Statistical significance was tested with unpaired two-sided t-test vs. control $(n=3 ; *, p \leq 0.05)$. 
the present work. In addition, combinational experiments have been performed, and one synthetic hybrid of both acids has been prepared and investigated. The motivation to covalently bind artesunic acid and betulinic acid can be explained by our previous excellent experiences with hybridization of parent compounds resulting in highly active lead structures. However, the newly synthesized ARTA-BETA hybrid is not outperforming its parent compounds. Nonetheless, variation of linkers might result in highly active hybrid molecules, since the type and the length of the linker play a crucial role for the biological activity of a hybrid drug. However, this is out of scope of the current study.

Altogether, our data reveal that the synthetic hybrid approach can enhance chemotherapeutic potential and helps in optimizing molecular features of therapy. The featured synthetic hybrid concept opens up the possibility of combination of virtually any molecular structure and thus unlimited variations.

\section{MATERIALS AND METHODS}

\section{Chemicals and general information}

Artesunic Acid (ARTA) and DMF were purchased from ABCR (Karlsruhe, Germany) and Sigma Aldrich (Taufkirchen, Germany) (95\% pure). Betulinic Acid (BETA) was purchased from ABCR (Karlsruhe, Germany) (90\% pure), additionally this compound was purified via column chromatography to achieve $>98 \%$ purity (Figure 5).

Thin layer chromatography (TLC) was performed on pre-coated aluminum sheets ALUGRAM $^{\circledR}$ SIL G/ UV254 (0.2 $\mathrm{mm}$ silica gel with fluorescent indicator, MachereyNagel \& Co). ${ }^{1} \mathrm{H}-\mathrm{NMR}\left({ }^{13} \mathrm{C}-\mathrm{NMR}\right)$ spectra were recorded at room temperature on a Bruker Avance spectrometer operating at $300 \mathrm{MHz}$. All chemical shifts are given in the ppm-scale and refer to the nondeuterized proportion of the solvent. ESI mass spectrum was recorded on a Bruker Daltonik micrOTOF II focus TOF MS-spectrometer. Elemental Analysis (C, H, N), carried out with an Elementar vario MICRO cube machine, is within $\pm 0.40 \%$ of the calculated values confirming a purity of $>95 \%$.

For our biological studies all drugs were solved under sterile conditions in dimethylsulfoxide (DMSO) to concentration of $20 \mathrm{mM}$.

\section{Synthesis of pentafluorophenyl ester of artesunic acid}

The solution of N,N'-dicyclohexylcarbodiimide in dry ethylacetate was added to a stirred solution of artesunic acid and pentafluorophenol in dry chloroform at $-20^{\circ} \mathrm{C}$ under nitrogen $\left(\mathrm{N}_{2}\right)$ atmosphere. The reaction mixture was stirred overnight at $0^{\circ} \mathrm{C}$. The precipitated urea was filtered and the solvent evaporated under vacuum. Afterwards, the crude was purified by column chromatography to give $89 \%$ of yield (Figure 3 ).

\section{Synthesis and characterization of $212 \mathrm{~A}$}

In a flame-dried flask under a nitrogen atmosphere, betulinic acid (150 mg, $0.33 \mathrm{mmol}, 1.0$ equiv.) was dissolved in anhydrous dimethylformamide (DMF) (1 $\mathrm{mL})$ under nitrogen $\left(\mathrm{N}_{2}\right)$ atmosphere. Artesunic acid pentafluorophenyl ester ( $181 \mathrm{mg}, 0.33 \mathrm{mmol}, 1.0$ equiv.), synthesized according to published procedure [17], was added to the solution of betulinic acid in anhydrous DMF under $\mathrm{N}_{2}$ atmosphere. The reaction mixture was stirred overnight. After removing the solvent under reduced pressure the obtained crude product was purified by column chromatography using the solvent mixture hexane/ethyl acetate, $\mathrm{Rf}=0.3$ ( hexane: ethylacetate 4:1 and indicated with phosphomolybdic acid) as eluent to yield hybrid $212 \mathrm{~A}$ with $75 \%$ yield as white powder (Figure 3 and Figure 5). Melting Point: $154.6{ }^{\circ} \mathrm{C} .{ }^{1} \mathrm{H}$ NMR $\left(300 \mathrm{MHz}, \mathrm{CDCl}_{3}\right): \delta=0.74(\mathrm{~m}, 12 \mathrm{H}), 0.86(\mathrm{~m}$, $10 \mathrm{H}), 1.15(\mathrm{~m}, 15 \mathrm{H}), 1,41(\mathrm{~s}, 7 \mathrm{H}), 1.53(\mathrm{~m}, 8 \mathrm{H}), 1.67$ (s, 4H), $1.84(\mathrm{~m}, 4 \mathrm{H}), 2.17(\mathrm{~m}, 3 \mathrm{H}), 2.53(\mathrm{~m}, 3 \mathrm{H}), 2.69$ $(\mathrm{s}, 2 \mathrm{H}), 2.97(\mathrm{~m}, 1 \mathrm{H}), 4,44(\mathrm{~m}, 1 \mathrm{H}), 4.59(\mathrm{~s}, 1 \mathrm{H}), 4.71$ $(\mathrm{s}, 1 \mathrm{H}), 5.41(\mathrm{~s}, 1 \mathrm{H}), 5.76(\mathrm{~d}, 1 \mathrm{H}) \mathrm{ppm} .{ }^{13} \mathrm{C}$ NMR $(75$ $\left.\mathrm{MHz}, \mathrm{CDCl}_{3}\right): \delta=12.10,14.65,15.99,16.16,16.53$, $18.13,19.32,20.20,20.84,21.98,23.62,24.56,25.44$, $25.94,27.98,29.28,29.33,29.67,30.50,30.92,31.78$, $32.12,34.09,34.22,36.21,37.00,37.09,37.26,37.83$, $38.34,40.69,42.42,45.23,46.87,49.23,50.40,51.57$, 55.42, 56.23, 80.10, 81.36, 91.48, 92.09, 104.44, 109.74, $150.35,171.17,171.81,179.65$ ppm. ESI-MS $[\mathrm{M}+\mathrm{Na}]^{+}$: calculated for $\left[\mathrm{C}_{49} \mathrm{H}_{74} \mathrm{NaO}_{10}\right]^{+}: 845.5180$, found 845.5174 . Purity of 212A was confirmed using elemental analysis. Anal. Calcd for $\mathrm{C}_{49} \mathrm{H}_{74} \mathrm{O}_{10}$ : C, 71.50; H, 9.06; Found: C, 70.98; H, 9.06.

\section{Cell culture glial cell lines}

Glioma cell lines (F98, U87) were obtained from ATCC/LGC-2397 (Germany). TN22 cells were generated from surgical resections of glioblastoma patients after informed consent. Cells were cultured under standard humidified conditions $\left(37^{\circ} \mathrm{C}, 5 \% \mathrm{CO}_{2}\right)$ with Dulbecco's Modified Eagle Medium (DMEM; Biochrom, Berlin, Germany) supplemented with $10 \%$ fetale bovine serum (Biochrom, Berlin, Germany), 1 \% Penicillin/ Streptomycin (Biochrom, Berlin, Germany) and $1 \%$ Glutamax (Gibco/Invitrogen, California, USA). Cells were passaged at approx. $90 \%$ confluence. For passaging cells were washed with PBS and trypsinized. After centrifugation $\left(900 \mathrm{xT}, 5 \mathrm{~min}, 24{ }^{\circ} \mathrm{C}\right)$ cells were plated into culture flask. 


\section{Cell culture primary neurons and astrocytes}

For hippocampal neuronal cultures one to four days old Wistar rats (Charles River, USA) were sacrificed. After removing the hippocampi from the brain they were transferred into ice cold Hank's salt solution. The dentate gyrus was cut away. The so obtained brain tissue was trypsinized $(5 \mathrm{mg} / \mathrm{ml})$, triturated mechanically and plated into 12-well-plates with MEM medium, supplemented with $10 \%$ fetal calf serum and 2\% B27 Supplement (all from Invitrogen, Taufkirchen). After a short time period the medium was replaced with Neurobasal A (Invitrogen, Taufkirchen) and neurons were kept until full differentiation.

\section{Cell proliferation analysis and toxicity assay}

The cell viability assay was performed using 3(4,5 dimethylthiazol) - 2,5 diphenyltetra-zolium (MTT) assay according to Hatipoglu et al. [36]. 3000 cells/ well were plated in 96-well plates, the drug treatment followed two hours later. After 72 hours cells were incubated with MTT solution (Roth, Karlsruhe, Germany) $(5 \mathrm{mg} / \mathrm{ml})$ for $4 \mathrm{~h}$ at $37^{\circ} \mathrm{C}, 5 \%$ $\mathrm{CO}_{2}$. The following lysis of the cells occurred with $100 \mu \mathrm{l}$ isopropanol $+\mathrm{HCl}(110 \mathrm{ml}$ Isopropanol +330 $\mu \mathrm{HCl})$ for 30 minutes. The mentioned setting was used for the cells F98, U87 and TN22. Primary neurons and astrocytes were seeded into 12-well plates and treated at day 44. After $72 \mathrm{~h}$ cells were incubated with MTT solution as described earlier. After $4 \mathrm{~h}$ cell lysis was performed with $200 \mu$ isopropanol + HCL. 90 $\mu l$ of this solution was transferred into 96-well plate for measuring with the microplate reader. The optical density of each well was measured using the microplate reader Tecan Infinite F50 (Crailsheim, Germany) set to $550 \mathrm{~nm}$ (wavelength correction set to $690 \mathrm{~nm}$ ) using i-control software. Cells without drug treatment were used as control. The viability of the different drug treatments is expressed as the percentage of control.

\section{Cell death assay and apoptosis analysis}

For the cell death assay cells were plated and treated the same way as the MTT assay. Cells were incubated with propidium iodide staining (PI) (Invitrogen, Darmstadt, Germany) for $20 \mathrm{~min}[1 \mu \mathrm{g} /$ $\mathrm{ml}$. Images were taken with Olympus x71 and cell-FSoftware (Olympus, Tokyo, Japan). For further analysis 200.000 cells/well were seeded into 6-well-plate and treated after $2 \mathrm{~h}$ with $10 \mu \mathrm{M}$. After $24 \mathrm{~h}$ medium was collected and cells were trypsinized. Cells were washed with PBS and stained with $0,1 \%$ Annexin V and 0,1\% 7-ADD (Biolegend, San Diego, USA). Results were analyzed by Flow Cytometer BD FACSCanto II (BD Bioscience, Heidelberg, Germany).

\section{Phalloidin staining procedure}

Actin staining was performed as described previously [37]. Briefly, for phalloidin staining approx. 20000 cells/well were seeded onglass cover slides and treated after 7 hours. $48 \mathrm{~h}$ after plating cells were fixated with PFA 4\% and stained with Phalloidin 488 (1:50) and Hoechst (1:10 000). Images were taken by an Axio Observer with the Zen Software (Zeiss, Oberkochen, Germany).

\section{Fluorescence microscopic imaging}

Neurons were treated with novel compounds and their respective solvent controls for $72 \mathrm{~h}$. Afterwards, cells were fixed with $4 \%$ formaldehyde. They were stained with $\beta$-III-tubulin marker (1:500, Promega, Madison, Wisconsin, USA), astrocytes with GFAP marker (1:500, Dako, Glostrup, Denmark) and the DNA with Hoechst33258 (1:10 000, Life Technologies, Darmstadt, Germany). Pictures were taken by an Axio Observer with the Zen Software (Zeiss, Oberkochen, Germany).

\section{Cell migration assay}

For migration assay 100.000 cells/well were plated into a 12-well-plate and cultured. After $36 \mathrm{~h}$ a scratch was made across the cell layer with a sterile pipette tip. After imaging the cells $(0 \mathrm{~h})$ cells were treated with different concentrations of the compounds. Images were taken with Olympus x71 and cell-F-Software (Olympus, Tokyo, Japan) at various times. To quantify the data, the distance between cells was measured using Image $\mathrm{J}$ software.

\section{Statistical analysis}

Quantitative data from experiments were obtained as stated in the figure legend. Analysis was performed using unpaired Student's $t$ test if not otherwise stated (MS Excel). Data from all experiments were obtained from at least three independent experiments. The level of significance was set at $*=\mathrm{p}<0.05$. Error bars represent \pm SEM.

\section{Ethical statements}

Studies with human tissue were conducted in compliance with the Helsinki Declaration and approved by the Ethics Committee of the Friedrich-Alexander University of Erlangen-Nuremberg.

\section{Author contributions}

N.E.S. and S.B.T. conceived the research. A.Ç.K. and S.B.T. designed the compounds for biological studies. The chemical synthesis was performed by A.Ç.K. and supervised by S.B.T. All bioassays were performed by A.A. with help from A.G. A.A., I.Y.E. and N.E.S. analyzed the experiments, interpreted and discussed the 
data. N.E.S. and A.A. wrote the paper in conjunction with all authors. All authors contributed to the preparation of the final manuscript and lent shape to the final paper. A.A. performed the present work in fulfillment of the requirements for obtaining the degree Dr. med. at the Medical Faculty of the Friedrich-Alexander University of Erlangen-Nürnberg (FAU).

\section{ACKNOWLEDGMENTS}

We thank all members of the Translational Cell Biology \& Neurooncology lab for valuable comments on this study and helpful suggestions. We thank Carmen Christoph (Department of Psychiatry, Universitätsklinikum Erlangen) for providing primary neurons and astrocytes.

We are grateful to the Deutsche Forschungsgemeinschaft (Grant Nr. TS 87/16-3), Wilhelm SanderStiftung (Grant Nr. 2014.019.1), the Graduate School Molecular Science (GSMS) and Interdisciplinary Center for Molecular Materials (ICMM) for generous research support. Financial support by the German Academic Exchange Service DAAD (doctoral research fellowship for Aysun Capcı Karagöz) is also gratefully acknowledged.

\section{CONFLICTS OF INTERESTS} of interest.

The authors declare no competing financial conflicts

\section{REFERENCES}

1. Kohler BA, Ward E, McCarthy BJ, Schymura MJ, Ries LA, Eheman C, Jemal A, Anderson RN, Ajani UA, Edwards BK. Annual report to the nation on the status of cancer, 1975-2007, featuring tumors of the brain and other nervous system. J Natl Cancer Inst. 2011; 103: 714-736.

2. Eyupoglu IY, Buchfelder M, Savaskan NE. Surgical resection of malignant gliomas-role in optimizing patient outcome. Nat Rev Neurol. 2013; 9: 141-151.

3. Nishikawa R. Standard therapy for glioblastoma - a review of where we are. Neurol Med Chir (Tokyo). 2010; 50: 713-719.

4. Stupp R, Brada M, van den Bent MJ, Tonn JC, Pentheroudakis G, ESMO Guidelines Working Group. High-grade glioma: ESMO Clinical Practice Guidelines for diagnosis, treatment and follow-up. Ann Oncol / ESMO. 2014; 25: iii93-101.

5. Wen PY, Kesari S. Malignant gliomas in adults. N Engl J Med. 2008; 359: 492-507.

6. Auffinger B, Spencer D, Pytel P, Ahmed AU, Lesniak MS. The role of glioma stem cells in chemotherapy resistance and glioblastoma multiforme recurrence. Expert Rev Neurother. 2015; 15: 741-752.
7. Nakada M, Minamoto T. [Drug repositioning in neurooncology-targeting GSK3 $\beta$ for glioblastoma]. [Article in Japanese]. Gan To Kagaku Ryoho. 2014; 41: 720-724.

8. Newman DJ, Cragg GM. Natural products as sources of new drugs from 1981 to 2014. J Nat Prod. 2016; 79: 629-661.

9. Smith PF, Ogundele A, Forrest A, Wilton J, Salzwedel K, Doto J, Allaway GP, Martin DE. Phase I and II study of the safety, virologic effect, and pharmacokinetics/pharmacodynamics of single-dose 3-o-(3',3'-dimethylsuccinyl)betulinic acid (bevirimat) against human immunodeficiency virus infection. Antimicrob Agents Chemother. 2007; 51: 3574-3581.

10. Mehta G, Singh V. Hybrid systems through natural product leads: an approach towards new molecular entities. Chem Soc Rev. 2002; 31: 324-334.

11. Tietze LF, Bell HP, Chandrasekhar S. Natural product hybrids as new leads for drug discovery. Angew Chem Int Ed Engl. 2003; 42: 3996-4028.

12. Ganesan A. Natural products as a hunting ground for combinatorial chemistry. Curr Opin Biotechnol. 2004; 15: 584-590.

13. Meunier B. Hybrid molecules with a dual mode of action: dream or reality? Acc Chem Res. 2008; 41: 69-77.

14. Tsogoeva SB. Recent progress in the development of synthetic hybrids of natural or unnatural bioactive compounds for medicinal chemistry. Mini Rev Med Chem. 2010; 10: 773-793.

15. Fröhlich T, Capci Karagöz A, Reiter C, Tsogoeva SB. Artemisinin-derived dimers: potent antimalarial and anticancer agents. J Med Chem. 2016; 59: 7360-7388.

16. Effenberger K, Breyer S, Schobert R. Terpene conjugates of the Nigella sativa seed-oil constituent thymoquinone with enhanced efficacy in cancer cells. Chem Biodivers. 2010; 7: 129-139.

17. Horwedel C, Tsogoeva SB, Wei S, Efferth T. Cytotoxicity of artesunic acid homo- and heterodimer molecules toward sensitive and multidrug-resistant CCRF-CEM leukemia cells. J Med Chem. 2010; 53: 4842-4848.

18. Reiter C, Capci Karagöz A, Fröhlich T, Klein V, Zeino M, Viertel K, Held J, Mordmuller B, Emirdag Ozturk S, Anil H, Efferth T, Tsogoeva SB. Synthesis and study of cytotoxic activity of 1,2,4-trioxane- and egonol-derived hybrid molecules against Plasmodium falciparum and multidrugresistant human leukemia cells. Eur J Med Chem. 2014; 75: 403-412.

19. Reiter C, Fröhlich T, Gruber L, Hutterer C, Marschall M, Voigtlander C, Friedrich O, Kappes B, Efferth T, Tsogoeva SB. Highly potent artemisinin-derived dimers and trimers: synthesis and evaluation of their antimalarial, antileukemia and antiviral activities. Bioorg Med Chem. 2015; 23: 5452-5458.

20. Reiter C, Fröhlich T, Zeino M, Marschall M, Bahsi H, Leidenberger M, Friedrich O, Kappes B, Hampel F, Efferth $\mathrm{T}$, Tsogoeva SB. New efficient artemisinin derived agents 
against human leukemia cells, human cytomegalovirus and Plasmodium falciparum: 2nd generation 1,2,4-trioxaneferrocene hybrids. Eur J Med Chem. 2015; 97: 164-172.

21. Reiter C, Herrmann A, Capci A, Efferth T, Tsogoeva SB. New artesunic acid homodimers: potent reversal agents of multidrug resistance in leukemia cells. Bioorg Med Chem. 2012; 20: 5637-5641.

22. Tu Y. The discovery of artemisinin (qinghaosu) and gifts from Chinese medicine. Nat Med. 2011; 17: 1217-1220.

23. Hamacher-Brady A, Stein HA, Turschner S, Toegel I, Mora R, Jennewein N, Efferth T, Eils R, Brady NR. Artesunate activates mitochondrial apoptosis in breast cancer cells via iron-catalyzed lysosomal reactive oxygen species production. J Biol Chem. 2011; 286: 6587-6601.

24. Efferth T, Giaisi M, Merling A, Krammer PH, Li-Weber M. Artesunate induces ROS-mediated apoptosis in doxorubicin-resistant T leukemia cells. PLoS One. 2007; 2: e693.

25. Sukhai MA, Prabha S, Hurren R, Rutledge AC, Lee AY, Sriskanthadevan S, Sun H, Wang X, Skrtic M, Seneviratne A, Cusimano M, Jhas B, Gronda M, et al. Lysosomal disruption preferentially targets acute myeloid leukemia cells and progenitors. J Clin Invest. 2013; 123: 315-328

26. Eling N, Reuter L, Hazin J, Hamacher-Brady A, Brady NR. Identification of artesunate as a specific activator of ferroptosis in pancreatic cancer cells. Oncoscience. 2015; 2: 517-532. doi: 10.18632/oncoscience. 160 .

27. Button RW, Lin F, Ercolano E, Vincent JH, Hu B, Hanemann CO, Luo S. Artesunate induces necrotic cell death in schwannoma cells. Cell Death Dis. 2014; 5: e1466.

28. Whibley CE, McPhail KL, Keyzers RA, Maritz MF, Leaner VD, Birrer MJ, Davies-Coleman MT, Hendricks DT. Reactive oxygen species mediated apoptosis of esophageal cancer cells induced by marine triprenyl toluquinones and toluhydroquinones. Mol Cancer Ther. 2007; 6: 2535-2543.

29. Fulda S, Jeremias I, Steiner HH, Pietsch T, Debatin KM. Betulinic acid: a new cytotoxic agent against malignant brain-tumor cells. Int J Cancer. 1999; 82: 435-441.
30. Pisha E, Chai H, Lee IS, Chagwedera TE, Farnsworth NR, Cordell GA, Beecher CW, Fong HH, Kinghorn AD, Brown DM, Mansukh CW, Monroe EW, Tina JH, et al. Discovery of betulinic acid as a selective inhibitor of human melanoma that functions by induction of apoptosis. Nat Med. 1995; 1: 1046-1051.

31. Saha S, Ghosh M, Dutta SK. A potent tumoricidal co-drug 'Bet-CA' - an ester derivative of betulinic acid and dichloroacetate selectively and synergistically kills cancer cells. Scientific Rep. 2015; 5: 7762.

32. Wick W, Grimmel C, Wagenknecht B, Dichgans J, Weller M. Betulinic acid-induced apoptosis in glioma cells: a sequential requirement for new protein synthesis, formation of reactive oxygen species, and caspase processing. J Pharmacol Exp Ther. 1999; 289: 1306-1312.

33. Rajendran P, Jaggi M, Singh MK, Mukherjee R, Burman AC. Pharmacological evaluation of C-3 modified Betulinic acid derivatives with potent anticancer activity. Invest New Drugs. 2008; 26: 25-34.

34. Csuk R. Betulinic acid and its derivatives: a patent review (2008-2013). Expert Opin Ther Pat. 2014; 24: 913-923.

35. Liby KT, Yore MM, Sporn MB. Triterpenoids and rexinoids as multifunctional agents for the prevention and treatment of cancer. Nat Rev Cancer. 2007; 7: 357-369.

36. Hatipoglu G, Hock SW, Weiss R, Fan Z, Sehm T, Ghoochani A, Buchfelder M, Savaskan NE, Eyupoglu IY. Sunitinib impedes brain tumor progression and reduces tumor-induced neurodegeneration in the microenvironment. Cancer Sci. 2015; 106: 160-170.

37. Ghoochani A, Yakubov E, Sehm T, Fan Z, Hock S, Buchfelder M, Eyupoglu IY, Savaskan NE. A versatile ex vivo technique for assaying tumor angiogenesis and microglia in the brain. Oncotarget. 2016; 7: 1838-1853. doi: 10.18632/oncotarget.6550. 